УДК 9

DOI 10.21661/r- 496437

\title{
Н.Г. Шарафян
}

\section{ВЛИЯНИЕ ПОСЛЕДСТВИЙ ГЕНОЦИДА В ДАРФУРЕ НА ЕГО ЖЕРТВЫ И СТЕПЕНЬ ОСУЖДЕНИЯ ДАННОГО ПРЕСТУПЛЕНИЯ}

Аннотация: геночид в Дарфуре является одним из самых страшных преступлений, совершенных против человечества в XXI веке, который вынудил примерно треть населения данной территории покинуть свои дома и жить в лагерях беженцев. Автор утверждает, что последствия этого преступления были ужасными как для Дарфура, так и для жертв геноџида. В статье рассматриваются основные последствия этого катастрофического преступления для населения Дарфура, одновременно анализируются недостатки судебной системь Судана и степень осужденнности данного преступления.

Ключевье слова: Дарфур, Судан, геночид, этнические группы, преступность, земля, голод, бежениы, обвинение, доказательство.

\section{N.G. Sharafyan}

\section{IMPACT OF THE CONSEQUENCES OF THE GENOCIDE IN DARFUR ON ITS VICTIMS AND THE LEVEL OF CONDEMNATION OF THE CRIME}

Abstract: genocide in Darfur is one of the most terrible crimes committed against humanity in the 21st century, that forced approximately one-third of the population of the territory to leave their homes and move to refugee camps. The author states, that the consequences were disastrous both for Darfur and its victims. The article renders main consequences of the catastrophic crime against the people of Darfur, analyzes drawbacks of Sudan juridical system and the level of condemnation of the crime.

Keywords: Darfur, Sudan, ethnic groups, hunger, refugees, accusation, proof. 


\section{Введение}

Изучение последствий преступления геноцида, известного в международном уголовном праве, как представляющего из себя высшую общественную опасность, имеет большое значение, как для признания исторических фактов, так и для выявления его особенностей и возможного осуждения данного преступления. В рамках этой статьи мы попытаемся обсудить влияние организованных преступных событий в Дарфуре на местное чернокожее население, а также степень их осуждения с юридической точки зрения. Вышеперечисленные вопросы имеют первостепенное значение, особенно принимая во внимание тот факт, что события, ставшие предметом обсуждения в данной статье, произошли относительно недавно, что свидетельствует о наличии многих исторических и юридических источников на эту тему.

\section{I. Влияние последствий геночида в Дарфуре на его жертв}

Война в Дарфуре стала причиной массовой расправы и насилия мужчин, женщин и детей, проживающих в этом районе. Дарфурская война - один из самых ужасных кризисов XXI века, свидетелями последствий которых мы являемся по сей день, в частности, в виде массового переселения жителей Дарфура в соседние страны.

В результате актов геноцида, Дарфур оказался в ужасном состоянии. В регионе нет элементарных условий для обеспечения благополучной жизни, Постконфликтный Дафур можно описать следующими явлениями: преобладающий голод, эпидемии и бездомность населения. Дарфурская война вынудила треть населения покинуть свои дома и переехать в лагеря для беженцев. Однако одновременно с насилием продолжало расти напряжение между оппозицией и властями [10].

\section{Голод}

Голод и нехватка продовольствия в Судане были обычным явлением. В 1980-х годах засуха и голод в Восточной Африке оказали влияние на образ жизни суданского населения и его дальнейшее развитие. В частности, Дарфур был регионом, наиболее пострадавшим от засухи. В будущем массовые убийства 
только лишь усугубили положение населения, в результате которого по меньшей мере 180000 жителей Судана умерли от голода и от связанных с ним заболеваний в 2003-2004 годах.

Многие из преодолевших данный конфликт, по-прежнему живут в лагерях беженцев, где повседневная жизнь создает невероятные трудности, особенно для уязвимых групп, в том числе и детей, полноценный день которых проходит без какой-либо еды [4].

\section{Массовые переселения}

Последствия актов геноцида в Дарфуре оказали катастрофическое воздействие на весь регион. В будущем, вероятно, 2,5 миллиона беженцев больше не будут иметь возможности вернуться в свои дома. Все пострадавшие были вынуждены переехать в Чад и Центральноафриканскую Республику. В настоящее время в Чаде всего 500000 беженцев, и власти страны не могут разместить всех этих людей. И если данный вопрос не будет в последующем решен, между странами может возникнуть конфликт. Как уже упоминалось, беженцы не имеют стабильных условий для обеспечения благополучной жизни. У них нет никаких природных ресурсов и возможности пользоваться социальными услугами.

8 ноября 2004ого года, Представитель Генерального секретаря ООН Судана и Координатор по гуманитарным вопросам Ален Нудехун отметил: «Число людей, пострадавших в результате конфликта в Дарфуре оценивается в 2,27 миллиона человек, то есть одна треть предконфиликтного населения Дарфур в 6,3 млн человек.» $[7$, p. 2, 3]. Общее число беженцев в Дарфуре составляет 1,65 миллион людей, а число, получивших помощь от гуманитарных организаций - около 627000 людей. Самый высокий уровень потерь представляется в Западном Дарфуре и составляет 833,036 человек [7, р. 61]. Кроме того, в 2004 году Управление Верховного комиссара ООН по делам беженцев (УВКБ) сообщило, что 203,051 людей в регионе Дарфур живут в лагерях и одиннадцати других районах, в частности, в восточной части Чада близ границы с Суданом [8, p. 29, 30]. 


\section{Уничтожение имущества}

Несмотря на то, что массовое перемещение населения Дарфура стало основным показателем гуманитарной катастрофы в регионе, широкомасштабное разрушение деревень является еще одним важным неоспоримым последствием этих ужасающих событий.

Лишь небольшому проценту жителей удалось вернуться обратно в свои дома. Сгорело большое количество имущества. Конфликт в Дарфуре все еще продолжается. Только 52825 человека из 215 022, переселенных из нескольких районов Дарфура, вернулись в Северный Дарфур, в частности в Сараф Охра. Однако, по оценкам ООН, около 748000 беженцев проживают в Судане, Чаде, Эфиопии и в лагерях беженцев, находящимся в Южном Судане. Кроме того, в лагерях беженцев проживает в общей сложности 2,7 миллиона жителей Дарфура, и более 4,7 миллиона дарфурцев получают гуманитарную помощь [8, p. 32].

В дополнение к сжиганию жилых домов, были также уничтожены инструменты для обработки пищевых продуктов. Во многих городах были разрушены не только имущество, но и многие общественные здания, постройки и учреждения, больницы, школы и полицейские управления.

\section{Урон экологии}

Согласно докладу Организации Объединенных Наций об окружающей среде, конфликт Дарфура в Судане оказал негативное воздействие не только на население, но и на природу, нанося ущерб лесам и разрушая земли.

Были все основания полагать, что военные начали зарабатывать деньги, занимаясь куплей-продажей деревьев. Знаменитый лес Кудава в Ниале был разрушен с 2005 года из-за масштабной вырубки лесов и в соответствии с докладом ООН об окружающей среде, разрушение рассматривается многими как трагедия, которую можно было бы предотвратить [8, p. 62]. В докладе содержится призыв к организациям начать проведение экологических кампаний в регионе, а также провести испытания использования альтернативных источников вентиляции и строительных материалов. 


\section{II. Степень осуждения преступления}

Чтобы понять уровень осуждения данного преступления, мы должны сначала изучить полноценность состава преступления:

- объективная сторона (Actus rea), что подразумевает полное или частичное уничтожение национальной, этнической, расовой или другой социальной группы;

- субъективная сторона (Mens rea), что, в свою очередь, представляет намерение полностью или частично уничтожить национальную, этническую, расовую или другую социальную группу [2].

Вышеупомянутые элементы преступления геноцида могут привести к серьезным нарушениям прав человека со стороны правительства, а также вооруженных сил, находящихся под его контролем.

Суданская система правосудия была неспособна или не желала бороться с ситуацией в Дарфуре. Эта система значительно ослабла за последние десять лет. Ограничения, которые предоставляют широкие полномочия исполнительной власти, подрывают эффективность судебной системы, и многие законы, которые в настоящее время действуют в Судане, противоречат основным стандартам прав человека. Уголовные законы Судана не устанавливают надлежащую уголовную ответственность за военные преступления и преступления против человечества, яркий пример которого произошло в Дарфуре. Кроме того, Уголовно-процессуальный кодекс этой страны содержит положения, препятствующие эффективному судебному разбирательству преступлений. Многочисленные жертвы сообщили Комиссии по правам человека ООН о том, что они не доверяют беспристрастности суданской системы правосудия и в последующем справедливом наказании лиц, совершивших преступные действия в Дарфуре [7, p. 5]. В любом случае, многие даже боятся возможного давления и преследований при обращении в национальную систему правосудия [7, p. 6, 7].

Усилия правительства по урегулированию кризиса были недостаточными и неэффективными, что способствовало формированию атмосферы вседозволенности и почти полной безнаказанности в Дарфуре. Лишь немногие жертвы 
осмелились протестовать против сформировавшейся ситуации в стране, несмотря на вышеперечисленные риски, которым они подвергали себя данными инициативами. В редких случаях, когда жалобы были поданы, надлежащее предварительное расследование не проводилось. Более того, существующие процедурные барьеры ограничивают возможности прибегнуть к системе правосудия для жертв. Несмотря на большие объемы кризиса и его огромное влияние на гражданское население Дарфура, правительство Судана предоставило Комиссии по правам человека информацию об очень немногих случаях преследования или даже наказания за преступные деяния.

Для решения вышеупомянутых проблем Комиссия рекомендовала правительству Судана принять ряд серьезных мер, в частности:

- прекратить военные преступления в Дарфуре и атмосферу безнаказанности за преступления против человечества;

- усилить независимость и беспристрастность судебной системы для надлежащего рассмотрения судебных дел по нарушению прав человека;

- предоставить Международному комитету Красного Креста и наблюдателям по правам человека Организации Объединенных Наций полную и беспрепятственную возможность общаться со всеми задержанными на основании ситуации в Дарфуре;

- обеспечить эффективную защиту прав человека всех жертв и свидетелей нарушений;

- в полной мере сотрудничать с соответствующими правозащитными организациями, с ООН и Африканским союзом;

- сразу после установления мира в Дарфуре создать комиссию по установлению истины и примирения [7, p. 76].

Тем не менее, возвращаясь к составу преступления геноцида, по мнению Комитета ООН по правам человека, наиболее важным элементом геноцида в Дарфуре является намерение полностью или частично уничтожить расовую, этническую, национальную или религиозную группу. Вместо этого создается впечатление, что те, кто планировал организовать и напасть на деревни, 
рассматривали в качестве основной мотивации не эксплуатацию, а изгнание жертв из своих домов, что якобы преследовало цель борьбы с коррупцией [7, p. 4].

По неоднократным заявлениям Совета Безопасности ООН, ситуация ставит под угрозу международный мир и безопасность. Комиссия подтвердила, что серьезные нарушения прав человека носят постоянный характер. Обвинение, выдвинутое прокурором против предполагаемых авторов совершившегося преступления, может способствовать восстановлению мира в Дарфуре.

Комиссия признала, что в некоторых случаях отдельные лица, в том числе правительственные чиновники, могут предпринимать действия, содержащие субъективный элемент геноцида. Совет Безопасности представил ситуацию в Дарфуре в Международный уголовный суд для расследования [3, p. 42] и в июне 2005ого года объявил о начале расследования. Международный прокурор предъявил обвинение президенту Судана Омар Аль-Баширу в совершении геноцида в Дарфуре и преступления против человечества ( включая убийства, разрушения, выселение населения, пытки, планирование военных преступлений и изнасилования)и объявил его в международный розыск, Судьи Палаты предварительного производства пришли к выводу, что «существуют разумные основания полагать», что Аль-Башир несет ответственность за преступления против человечества и совершение военных преступлений, включая убийство, пытки, выселение населения, изнасилование. Нападения на население и бежал. Однако судьи утверждали, что прокурор не смог обосновать существование намерения уничтожить полностью или частично этнические группы, являющиеся объектом геноцида [11].

В своем решении Палата предварительного расследования посчитала особенно важным подчеркнуть особый мотив геноцида и особый мотив преступления против человечества [5, p. 141-145]. Похоже, что это была явная попытка Палаты вернуть прокурора к его первоначальному обвинению, выдвинутого против министра внутренних дел Судана Ади в 2007 году, когда оправдание 
Прокурора было основано не на геноциде, а на совершении преступления против человечества [6, p. 176].

Данное решение Палаты рождает следующий вопрос: в чем логика изменения стратегии прокурора? Преимущества такой стратегии многочисленны. Проведение полного расследования на основе преступления против человечества безусловно облегчит процесс доказывания элементов состава преступления, чем попытка доказать совершение преступления геноцида, особенно его субъективный элемент (mens rea), то есть намерение полностью или частично уничтожить национальную, этническую или расовую группу. Это правильно отражает ситуацию в стране, и такая стратегия способствует полноценному признанию серьезных нарушений социальных, экономических и культурных прав, лежащих в основе конфликтов в Дарфуре [9, p. 206-211].

Таким образом, несмотря на то, что геноцид квалифицируется как «преступление преступлений» международного уголовного права [7], что почти сразу делает судебное разбирательство законным и заслуживающим доверия, преступление против человечества, будучи более гибким, дает более глубокое понимание сложившейся ситуации в Дарфуре. Поэтому представление различий и сходств Палатой предварительного производства и Трибуналом между двумя вышеперечисленными преступлениями можно охарактеризовать как своего рода четким посланием, адресованным Прокурору [1, р. 294]. Таким образом, Прокурор сможет восстановить нарушенные социальные, экономические и культурные права и устранить их в рамках Римского статута.

\section{References}

1. Cryer R., The Definitions of International Crimes in the Al Bashir Arrest Warrant Decision, 7 JICJ 283-296, 2009.

2. Convention on the Prevention and Punishment of the crime of Genocide, United Nations, December 9, 1948.

3. Explaining Darfur, Lectures on the Ongoing Genocide by Agnes van Ardenne, 2006. 
4. Hursh J., Hunger in Sudan: Government Policy, Civilian Suffering, Enough, March 11, 2016.

5. CC, Prosecutor v. Omar Hassan Ahmad Al Bashir, Decision on the Prosecution's Application for a Warrant of Arrest against Omar Hassan Ahmad Al Bashir, ICC-02/05-01/09, 4 March 2009.

6. ICC, Prosecutor v. Ahmad Muhammad Harun («Ahmad Harun») and Ali Muhammad Ali Abd-Al-Rahman («Ali Kushayb»), Warrant of Arrest for Ali Kushayb, Case No. ICC-02/05-01/07, 27 April 2007.

7. Report of the International Commission of Inquiry in Darfur to the United Nations Secretary-General, Geneva, 25 January, 2006.

8. Report of the United Nations Environment Programme, Sudan: Post-Conflict environmental assessment, June, 2007.

9. Schabas W., Genocide in International Law: the Crime of Crimes, Cambridge University Press, 2000.

10. Totten S., An Oral and Documentary History of the Darfur Genocide, (California, Praeger Security International, 2011.

11. Worldwide Movement for Human Rights, the International Court and Darfur, 2009.

Шарафян Нарек Гагикович - юрисконсульт министра в Министерстве экономического развития и инвестиций Республики Армения, магистрант Института арменоведческих исследований Ереванского государственного университета, Армения, Ереван.

Sharafyan Narek Gagikovich - undergraduate student of the Yerevan State University, Institute of Armenian Studies, department of Genocide Studies, Legal advisor to the Minister of Ministry of Economic Development and Investments of the Republic of Armenia, Armenia, Yerevan. 